\title{
INTERVIEW
}

\section{Translation as conversation: Ngũgĩ wa Thiong'o in Euskara}

\author{
Natasha Himmelman \& Pernando Barrena \\ Natasha Himmelman es una investigadora y educadora puertorriqueña/Latinx cuir. She is currently based at the \\ University of the Witwatersrand's Department of African Literature. \\ Email: natasha.himmelman@wits.ac.za \\ ORCID: https://orcid.org/0000-0003-4538-5461
}

Pernando Barrena is an accomplished translator. He was part of the first editorial team at Txalaparta, an independent Basque publishing house where he worked as Euskara Editor.

\section{DOI 10.17159/2309-9070/tvl.v.56i1.6279}

In 2018, from the Nuyorican Poets Café to the Auckland Writers Festival, we celebrated Ngũgĩ wa Thiong'o's $80^{\text {th }}$ birthday. And before the year came to a close, James Currey released Ngũgĩ: Reflections on His Life of Writing (2018), edited by Simon Gikandi and Ndirangu Wachanga. Indeed, it seems that honoring eight decades of the esteemed author could not be contained within a single year. Celebrations have continued into 2019, particularly with Ngũgĩ's return to Kenya and the launch of his $34^{\text {th }}$ book, Kenda Mũiyũru: Rũgano rwa Gĩkũyũ na Mũmbi (2019) (The Perfect Nine: The Story of Gikuyu and Mumbi). 2018 also marked 30 years of Txalaparta, "una editorial vasca, libre e independiente" (a Basque publisher, free and independent) (Txalaparta). ${ }^{1}$ Based in Navarre and committed to "la soberanía cultural e informative de nuestro país, Euskal Herria" (the cultural and knowledge sovereignty of Euskal Herria), the independent publisher works "ser altavoz de cualquier creación literaria que mejore la relación entre los pueblos del mundo, que ayude a transformer la realidad, que guarde la memoria histórica, que abra caminos a la diversidad, a las utopias" (to amplify any literary work that improves the relationship between the villages of the world, that helps to transform reality, that safeguards historical memory, that opens pathways to diversity, to utopias) (Txalaparta). It is this commitment and vision that inspired Txalaparta to publish an Euskara translation of Ngũgĩ's Weep Not, Child (1964)-Negarrik ez, haurra (1994).

This year, we celebrate the $25^{\text {th }}$ anniversary of that translation. Pernando Barrena remembers his time as Txalaparta editor and translator, speaking with excitement about his introduction to Ngũgĩ's work and African literature. With humor, he locates this labor at a time before social media, describing a kind of intellectual and cultural isolation that inspired a commitment to bring ideas, experiences, and knowledges to the Spanish market and to Euskal Herria.

Joining Txalaparta's founders-José Mari Esparza and Juanjo Marco—as Euskara Editor, Barrena was part of the first editorial team. The publisher describes these early years, explaining:

En aquel tiempo, levanta una editorial comprometida, progresista, independiente y vasco no 
era fácil. La transición había hecho desaparecer muchos sellos comprometidos con lo social y lo politico, y el mercado del libro se iba concentrando en cada vez menos manos. De las librerías habían desaparecido hasta los libros del Che Guevara. En el Estado apenas había libros vascos. A eso había que sumar la situación política vasca y las consecuencias de apostar por un relato propio: procesos judiciales, multas, biocots, amenazas [...]

At that time, launching a committed, progressive, independent, and Basque publishing house was not easy. The transition meant that many socially and politically committed presses had disappeared and that increasingly, the book market became concentrated into few hands. The books of Che Guevara had disappeared from bookstores. In Spain, there were hardly any Basque books. In addition, the Basque political situation and the consequences of betting on our own story: judicial processes, fines, boycotts, threats [...] (Txalaparta)

In response to this multi-layered and, many times, oppressive context, Txalaparta imagined new ways to engage and build its readership.

Today it has published nearly one thousand titles in Euskara and Castellano - "libros que cambian personas que cambian el mundo" (books that change people that change the world) (Txalaparta). Their catalogue includes work by African authors such as Samir Amin, Amilcar Cabral, Paulina Chiziane, Nawal el Saadawi, Ellen Kuzwayo, and Naguib Mahfouz (Txalaparta). Their dedication to translation legitimizes ways of being and knowing that resist a single, coherent or monolithic national subjectivity. And, in the case of Euskara in particular, translation has the potential to undercut the notion of a united (European) Spain.

Famously, in "A Statement" prefacing Decolonizing the Mind, Ngũgĩ (xiii) announced his "farewell to English," hopeful that with "the age-old medium of translation [he] shall be able to continue dialogue with all." Over the years, he has reconceived, reassessed, experimented, and reaffirmed his commitment to translation in his work. As Director of the International Center for Writing and Translation (ICWT) at the University of California, Irvine, he worked with writers, scholars, artists, and translators, imagining what "translation as conversation" could look like (Rodrigues 162). Txalaparta's work demonstrates what is possible.

NH: How did Txalaparta decide to translate and work with African literature in general and Ngũgís work in particular?

PB: We became aware of the richness of African literature through contacts we, as publishers, made at the Frankfurt Book fair in the early nineties. We became familiar with writers like Ngũgĩ wa Thiong'o, Artur Pestana (Pepetela), Ken Saro-Wiwa, Ellen Kuzwayo, Chinua Achebe, Naguib Mahfuz, Nadine Gordimer, Bessie Head [...] 
We became familiar with these authors after our first trips to the Frankfurt Fair. After that, we went to London, to Charing Cross, and visited the excellent bookstores there. There were dozens of authors published in English that were completely unknown to the Basque and Spanish public. I remember that we came back home with dozens of books. I must underline that this happened at the beginning of the nineties: no internet, no mobiles [...]

NH: In Negarrik ez, haurra, who did you imagine as your audience? What role do you think the publisher has in determining audience?

PB: My audience is Basque speakers interested in postcolonial literature, particularly African literature.

Txalaparta is a progressive publisher that works with authors that offer more than good writing. As a result, it is a referential publisher for those looking for literature and writers engaged with progressive values.

Txalaparta's audience is a good one for Ngũgĩ's work and its message, quite similar to Ngũgĩ's audience.

NH: In the same year that Weep Not, Child was published in Euskara, Txalaparta published Devil on the Cross in Castellano. Why do you think Weep Not, Child was chosen for translation into Euskara?

PB: I think that the storytelling with Weep Not, Child is quite a universal story. It powerfully reflects the profound effects of colonization, especially in the history of education and the profound effects colonial education has on people.

While the situation here is completely different, some concepts reflected in the work are universal, and we thought that they were going to be very well understood by our public, which strongly values education. Even under Franco's dictatorship before 1975, there was a strong movement here that stood for education in Basque. The will of the people sought an education of our own, an education offered in the local language, in Basque, and then the education that should be based in the Basque curricula, you know? Weep Not, Child is focused very much on education and this was one of the points that made us aware of the viability of this book and its potential to be well understood by the reader.

Overall, the struggle that appears among the main characters in the book is quite universal and we were confident that it would speak to our readers.

NH: In many ways, Txalaparta's commitment to translation speaks to discussions about language in African literature. Ngũgĩ's works, in particular, privileges translation. Are you familiar with these conversations? How do you think it might resonate with your Euskara-language audiences? 
PB: Well, it is the same debate all around the world when small local languages strive to survive by confronting imperial languages like English, French, Spanish, or others. The Basque community has also confronted this big debate: is literature written in Spanish by Basques, Basque literature itself? How can you struggle against the power of an overwhelming language like Spanish from the weaker compared wealth of the Basque language (600 000 speakers)?

I think with regard to the need for postcolonial thinking in language and cultural matters, Ngũgi's Decolonizing the Mind (1986), which is also translated into Basque, is a landmark in this debate. His approach has been widely followed by Basque language activists who feel that it is an issue that applies to linguistics but also politics and individual and collective rights.

When Decolonizing the Mind was published here in the Basque Country, there was a review of the book in the newspaper that opened a small debate between different people on the principle ideas of Ngũgĩ's work. It was used to discuss a debate that has been part of our culture for years; it is a debate that we have ourselves. We are living in the middle of the powerful Spanish State in the south and the powerful French State in the north. In comparison, we are a small community in terms of inhabitants, language, culture, and so on. Some writers here are defending, or were defending at that moment, that if a Basque writer writes in Castellano, that literature cannot be considered Basque but is rather Spanish literature written by a Basque author. On the other hand, some writers argued for the inclusion of literature made by a Basque person, whether it be in Spanish or French. Focusing on the benefit of the integration of different visions within Basque culture, these writers asserted that there is more to gain from a more open understanding of how and what defines Basque literature. It is a very interesting discussion, and there's significant overlap with Ngũgĩ's approach and some of the central ideas in Decolonizing the Mind.

NH: Given the significance of language in education and Basque literature, how does this orientation influence your translation of Ngugi's novel?

PB: Every language, and particularly small ones, brings its own cosmology. Basque cosmology offers the translation as a cultural bridge for the Basque reader.

In my own praxis, I focused on gathering information about the author, the work, and the historical context. Through my research, I became very sympathetic to Ngũgĩ's point of view, and I'd say that more than language, my connection to his stance was more influential to the final art.

NH: Recognizing the diversity within Basque, are there other languages, like Biscayan or Gipuzkoan, in your translation? 
PB: No. Most of the translation work into Basque is done into "standard" or "unified" Basque. Negarrik ez, haurra is not an exception.

NH: Celebrating the $25^{\text {th }}$ anniversary of your translation and 30 years of Txalaparta, how do you think perceptions of Africa have changed over the years?

PB: The African continent is not far from here. You have to cross southbound on the Spanish State and in 1000 kilometers you can be in Africa, across the Strait of Gibraltar. Because of that proximity, we have thousands of people who have come here in the last years from North Africa, mainly people from Morocco and Algeria.

Therefore, I would say that it is quite normal and familiar to know people from Morocco or Algeria. But I would say that despite knowing that people from North Africa are Africans and we know they come from North Africa, they do not represent what we have been trained to imagine as "African." Within this imaginary, "black" itself means "African." Of course, everybody knows that an Egyptian is an African or an Algerian is an African or a Sahrawi is an African, but it's not the same.

I am 53 and I remember when we were children and when we saw somebody black in the street. I remember that my brother asked if that man was made of chocolate. We didn't know there were black people. I would say that for the last decade, a lot of black people have come from different places, particularly Senegal and Equatorial Guinea. And yet, it's quite a new thing-the presence of blackness here.

\section{Acknowledgements}

Natasha Himmelman's work on translations of Ngũgĩ wa Thiong'o's writing has been supported by the Centre for African Studies at the University of Cape Town and the Department of African American Studies at the University of California, Berkeley. Thank you, Candela, Femi Eromosele and Polo Moji for your generous support.

\section{Notes}

1. All translations into English are by Natasha Himmelman.

\section{Works Cited}

Gikandi, Simon \& Ndirangu Wachanga, eds. Ngũgĩ: Reflections on His Life of Writing. James Currey, 2018. Ngũgĩ wa Thiong' o. Decolonising the Mind: The Politics of Language in African Literature. Zimbabwe Publishing House, 1994.

. Kenda Mũiyũru: Rũgano rwa Gĩkũyũ na Mũmbi. East African Educational Publishers, 2019.

. Negarrik ez, haurra. Trans. Pernando Barrena. Txalaparta, 1994. . Weep Not, Child. Heinemann, 1964.

Rodrigues, Ângela L. "Beyond Nativism: An interview with Ngugi wa Thiong'o." Research in African Literatures vol. 35, no. 3, 2004, pp. 161-7.

Txalaparta. Txalaparta Publishing House. https://www.txalaparta.eus/es/editorial-txalaparta. Accessed 12 Feb. 2019. 